\title{
Biochemical Properties and Cell Culture Affinity of Fowl Adenovirus Serotype-4 Strains Isolated from the Oviducts of Layer Hens in East Japan
}

\author{
Fletcher Padilla Del Valle, ${ }^{1,3 *}$ Sherwin Ibasco Camba, ${ }^{1,4}$ Dennis Villaseñor Umali, ${ }^{1,2,3}$ Kazumi Sasai, ${ }^{2}$ Kazutoshi Shirota, ${ }^{1}$ \\ and Hiromitsu Katoh ${ }^{1,2,3}$

\begin{abstract}
${ }^{I}$ Diagnostic and Research Division, Poultry Products Quality Control, 125-7 Daiwa Dakeonsen, Nihonmatsu-shi, Fukushima 964-0062, Japan ${ }^{2}$ Graduate School of Life and Environmental Sciences, Osaka Prefecture University, 1-58 Rinku-oraikita, Izumisano, Osaka 598-8531, Japan

${ }^{3}$ College of Veterinary Medicine, University of the Philippines Los Baños, College, Laguna 4031, Philippines

${ }^{4}$ College of Agriculture, University of the Philippines Los Baños, College, Laguna 4031, Philippines
\end{abstract} \\ "Corresponding author's Email: fpdelvalle@up.edu.ph; ORCID 0000-0003-2839-0568
}

\begin{abstract}
In the present study, the biochemical properties of two fowl adenovirus serotype-4 (FAdV4) sample strains were determined. These were previously isolated from the oviducts of laying chickens from two layer operations in East Japan, namely $\mathrm{M}$ and $\mathrm{Y}$ farms. Tests for stability and sensitivity, hemagglutinating (HA) activity, and growth in two different cell lines were performed. The results showed that the $\mathrm{M}$ farm strain, (Japan/Ibaraki/M-HB2/2016) was sensitive to $100 \%$ ethanol, $52^{\circ} \mathrm{C}$ and higher temperature, and formaldehyde. The Y farm strain (Japan/Ibaraki/Y$\mathrm{H} 6 / 2016$ ) was sensitive to $70 \%$ ethanol, $100 \%$ ethanol, $52^{\circ} \mathrm{C}$ and higher temperature, and formaldehyde. Both strains were stable against ether and chloroform, and lacked HA activity. To the best of the author's knowledge, these FAdV4 strains were the first to be detected and isolated from laying chicken's oviduct. Their biochemical characteristics; specifically, sensitivy to heat and formaldehyde, can be included in farm cleanup and disinfection protocol. This could help in reducing environmental contamination. The strains propagated well in chick embryo fibroblast $(\mathrm{CEF})$ as indicated by cytopathic effect (CPE) observation with positive AAV-PCR and FAdV4-PCR results. The strains failed to propagate in MDCC-MSB1 cells as indicated by the negative results in both CPE and PCR. It appears that MDCC-MSB1 cells are not suitable for FAdV4 cultivation. However, only non-pathogenic FAdV4 strains were used in this work. It was not confirmed if pathogenic strains have the same behavior, perhaps, further trials are advisable. Future studies may benefit from the reduction of use of primary cells from live animals. This information contributes to the current understanding of FAdV4 characteristics.
\end{abstract}

Keywords: Biochemical properties, Cell culture, Fowl adenovirus serotype 4, Laying hen, Oviduct.

\section{INTRODUCTION}

The family Adenoviridae is comprised of middle-sized, non-enveloped, icosahedral, double-stranded DNA viruses. There are five genera, namely Mastadenovirus, Aviadenovirus, Siadenovirus, Atadenovirus, and Ichtadenovirus (ICTV, 2018). Virions are $70-90 \mathrm{~nm}$ in size, hexagonal in shape, and have three exposed structural proteins. The hexon forms the capsid, the penton base anchors the fiber, and the fiber interacts with the cellular receptor. Many Adenoviruses (AdVs) bind with the coxsackie and adenovirus receptor (CAR) for cellular entry (Fujino et al., 2016). Some have single fiber protein, such as the case for most mammalian AdVs while others have two, including avian adenoviruses (AAVs) (Harrach et al., 2011).

The Fowl aviadenoviruses (FAdVs), also known as group-1 AAVs, are pathogens associated with important avian disease syndromes (Knowles, 2011). They are classified into five species (A to E) with 12 serotypes (1$8 \mathrm{a}, 8 \mathrm{~b}-11)$, wherein members are associated with certain diseases (Hess, 2017). Although implicated, the pathogenicity of FAdVs is not well-defined (Niczyporuk et al., 2012). These viruses may act as primary or secondary pathogens (Toro et al., 2001; Niczyporuk et al., 2013), and there are pathogenic and non-pathogenic strains. Additionally, FAdVs can be isolated from both 
healthy and sick chickens (McFerran and Smyth, 2000; Hess, 2017).

Serotypes are linked to poultry diseases. These include pathogenic FAdV1 to adenoviral gizzard erosion (GE, Grafl et al., 2012), pathogenic FAdV2, 8a, 8b, and 11, to inclusion-body hepatitis (IBH, Nakamura et al., 2011), and pathogenic FAdV4 to hydropericardiumhepatitis syndrome (HPS, Mc Ferran and Smyth, 2000; Joubert et al., 2014). These diseases have been replicated under controlled conditions (Okuda et al., 2006; Mase et al., 2010). At present, the genetic determinant of pathogenicity is still unclear. This is true for FAdV1 (Matczuk et al., 2017), FAdV11 (Absalón et al., 2017), and FAdV4 (Liu et al., 2016; Mo et al., 2019). Reported FAdV infections in Japan are mainly connected with increased mortality and this was observed in IBH and HPS cases (Nakamura et al., 2000; Mase et al., 2009; Nakamura et al., 2011). On the other hand, some GE cases did not have clinical signs (Ono et al., 2001).

The biochemical properties of viruses can be used to differentiate one from the other (Rovozzo and Burke, 1973) or to characterize different strains. There are numerous studies on the biochemical properties of FAdVs (Otsuki et al, 1976; Cook, 1983; Park et al., 2011). Integral to these studies is the cultivation of virus on cell cultures. FAdVs can propagate in both primary and transformed cell lines. Perhaps the most commonly used primary cells are chick kidney cells (CKC, Kawamura et al., 1964; Mase et al., 2010) chick embryo liver cells (CEL, McFerran and Smyth, 2000; Park et al., 2011), and chick embryo fibroblasts (CEF, Bauer et al., 1986; Niczyporuk et al., 2013). Transformed cell lines are also suitable for propagation, these include the QT35 (Schonewille et al., 2008) and LMH (Zhao et al., 2015). Other cell lines that have been used for FAdV affinity studies include the Crandel-Rees Feline Kidney (CRFK) cell and Vero cells (Taharaguchi et al., 2012).

Another viral property used for characterization is hemagglutinating activity (HA) (Rovozzo and Burke, 1973). Some viruses adsorb red blood cells (RBCs) through cellular receptors. This results in agglutination, otherwise known as hemagglutination (Rovozzo and Burke, 1973). Of the three structural proteins in AAVs, the fiber is the one responsible for HA activity (Louis et al., 1994). Some AAVs are known to have HA activity (Knowles et al., 2011) and some others do not. FAdVs from the field has been reported to be HA-negative (Otsuki et al., 1976).

Two FAdV4 strains were previously isolated from laying hens in two different farms, namely $\mathrm{M}$ and $\mathrm{Y}$ farms. Both are located in Ibaraki prefecture Japan and previously suffered from poor egg production. The $\mathrm{M}$ farm strain was named Japan/Ibaraki/M-HB2/2016, and the Y farm strain was entitled Japan/Ibaraki/Y-H6/2016. The hexon and fiber2 genes of both strains have been sequenced, and they have been reported as non-pathogenic (Del Valle et al., 2020a). Both M and Y farms receive their replacement pullets from the same replacement-pullet farm. That particular farm had a history of chick anemia virus (CAV) infections (Del Valle et al., 2020b). Retrospective testing of some CAV-positive samples has indicated avian adenovirus (AAV) coinfection as well (Del Valle, 2019, Table 5).

The present study aimed to investigate the biochemical properties and propagation of $\mathrm{M}$ farm and $\mathrm{Y}$ farm strains in cell culture. More specifically, the study was designed to determine their stability and sensitivity, HA activity, and affinity to two different cell lines. In this regard, CEF and MSB1 cells were used for cell culture growth comparison.

\section{MATERIALS AND METHODS}

\section{Viruses}

The FAdV4 strains used in the present study were Japan/Ibaraki/M-HB2/2016 and Japan/Ibaraki/Y-H6/2016, previously isolated from the oviducts of laying hens (Del Valle et al., 2020a). The KR5 strain was used as a positive control.

\section{Biochemical properties}

Previously described methods for determining viral titer and biochemical properties were performed. Ten heads of 5- to 7-day-old specific-pathogen-free (SPF) chicks were sacrificed by cervical dislocation, then, the kidneys were collected for CKC cultivation following previously described methods with slight modifications (Rovozzo and Burke, 1973). Titration was done in 6-well plates with 1 plate assigned to each dilution from $10^{-1}$ to $10^{-10}$. In every plate, each well served as a replicate and was seeded with $900 \mu 1$ EMEM containing CKC, and later, $100 \mu \mathrm{l}$ of virus solution was added. All plates were incubated at $40^{\circ} \mathrm{C}$ in $5 \% \mathrm{CO}_{2}$ and observed for Cytopathic Effect (CPE) until day 5. The endpoint dilution was computed using the Reed and Muench method (Reed and Muench, 1938). The $\mathrm{Y}$ farm titer in CKC was $10^{6.75} \mathrm{TCID}_{50} / \mathrm{ml}$, and that of $\mathrm{M}$ farm strain was $10^{5.40} \mathrm{TCID}_{50} / \mathrm{ml}$. The viral fluids were exposed to various chemical and physical agents (Rovozzo and Burke, 1973). The titer was computed using the Reed and Muench method (Reed and Muench, 1938), and a drop of $1 \log _{10}$ from the baseline $\mathrm{TCID}_{50}$ indicated sensitivity (Rovozzo and Burke, 1973). 


\section{Sensitivity to chloroform}

Virus suspensions were centrifuged to remove cellular debris and $500 \mu \mathrm{l}$ chloroform was added to $1 \mathrm{ml}$ undiluted virus suspension. These were mixed manually for 10 minutes at room temperature, followed by centrifugation at $33 \mathrm{x}$ g for 5 minutes. The uppermost clear layer was diluted 10-fold and used for titration in CKC.

\section{Sensitivity to ether}

In this phase, $200 \mu \mathrm{l}$ ether was mixed with $800 \mu \mathrm{l}$ virus suspension to form a $20 \%$ solution. These were shaken manually and kept at $4^{\circ} \mathrm{C}$ for $18-24$ hours with intermittent shaking. The suspensions were transferred to sterile Petri dishes and the ether was allowed to evaporate for 1 hour. After evaporation of ether, the fluid was diluted 10-fold followed by titration in CKC.

\section{Sensitivity to ethanol}

Viral isolates were mixed with ethanol at varying concentrations of $50 \%, 70 \%$, and $100 \%$. Then, $0.5 \mathrm{ml}$ of virus fluid was mixed with $0.25 \mathrm{ml} 50 \%$ ethanol solution in a micro centrifuge tube, and was incubated at room temperature for 1 hour. The mixture was placed in a petri dish and allowed to air-dry for 30 minutes; after which it was diluted 10-fold, and titrated in CKC. The same method was used for $75 \%$ and $100 \%$ ethanol.

\section{Sensitivity to formaldehyde}

Formaldehyde and distilled water were mixed to form 1:2000 solution. In this regard, $1 \mathrm{ml}$ of solution and $1 \mathrm{ml}$ virus fluid were mixed and incubated at $37^{\circ} \mathrm{C}$ for 1 hour. The mixture was diluted 10-fold and titrated in CKC.

\section{Sensitivity to heat}

At this stage, $500 \mu$ undiluted viral suspensions were placed in microcentrifuge tubes. These were immersed in water baths with temperatures of: $50^{\circ} \mathrm{C}, 52^{\circ} \mathrm{C}, 54^{\circ} \mathrm{C}$, and $58^{\circ} \mathrm{C}$ for 30 minutes. The solutions were cooled in the icecold water bath, diluted 10-fold, and titrated in CKC.

\section{Hemagglutinating activity}

Hemagglutination (HA) test was performed using previously described methods by Rovozzo and Burke (1973) with slight modifications. Chicken RBCs were collected by centrifugation at $205 \mathrm{x}$ g for 10 minutes as described by Rovozzo and Burke (1973) and used to prepare $0.5 \%$ suspension on phosphate buffered saline (PBS). In a 96-well microtiter plate, $50 \mu \mathrm{l}$ of 2 -fold serial dilutions of the virus was prepared in PBS. A DAdV-A strain was used as a positive control. In the next step, $50 \mu \mathrm{l}$ of $0.5 \% \mathrm{RBC}$ was added to all wells and was kept at room temperature for 30 minutes, afterwards, these were checked for agglutination reaction.

\section{Growth comparison in two cell cultures}

Chick embryonic fibroblasts (CEF) cells were cultivated and inoculated using previously described methods with slight modifications (Rovozzo and Burke, 1973). The MDCC-MSB1 cells were cultivated using previously described methods with slight modifications (Simeonov et al., 2014). After inoculation with the FAdV4 strains, the cell cultures were incubated at $40^{\circ} \mathrm{C}$ in $5 \% \mathrm{CO}_{2}$ and observed for 2 to 5 days, and then passaged until CPE was observed. For confirmation, AAV and FAdV4-PCR (Mase et al., 2009; Mase et al., 2010) were performed at different passages, meaning that first to sixth for CEF and first, second, third, fifth, eighth, and thirteenth for MSB1 cell (Table 1).

\section{RESULTS}

\section{Biochemical properties}

Both $\mathrm{M}$-farm and Y-farm strains were sensitive to $100 \%$ ethanol, $52^{\circ} \mathrm{C}$ and higher temperature, and formaldehyde. These were stable against chloroform, ether, and $50^{\circ} \mathrm{C}$. Stability to $70 \%$ ethanol was variable, the M-farm strain was stable and the Y-farm strain was sensitive (Table 2).

\section{Hemagglutination}

The KR5, M-farm, and Y-farm strains lacked HA activity. The DAdV-A positive control had 4096 HA units (Table 3).

\section{Growth comparison in two cell cultures}

\section{Chicken embryo fibroblast}

After 5-6 days of incubation, CPE was observed on infected CEF inoculated with KR5, M-farm strain, and Yfarm strain. Cellular swelling, death, and monolayer destruction were evident 5-6 days post-infection. All three strains produced the same effect from the first passage until the sixth (Figure 1). The viral fluids also had positive results in AAV and FAdV-4 PCR in every generation (Figure 4 and Table 4).

\section{MSB1 cells}

After 2-4 days of incubation, no color change in the media was observed on virus-inoculated plates (Figure 2). From passages 1 to 13 , the results were the same for all three strains (Figures 2 and 3, and Table 4). The AAV and FAdV-4 PCR assays were positive only at the first passage, weak positive at the second, and negative on the third, fifth, eighth, and thirteenth passages. The CAV-livevaccine produced cell swelling and crenation in MSB1 cells starting at the third passage, with cellular death at the fourth (Figure 3 and Table 4). 
Table 1. Primer and PCR conditions used for viral genome detection

\begin{tabular}{|c|c|c|c|c|c|c|c|c|c|c|c|}
\hline Assay & Target virus & & Primer $\left(5^{\prime}-3 '\right)$ & $\begin{array}{c}\text { Initial } \\
\text { Denaturation }\end{array}$ & Denaturation & Annealing & Extension & $\begin{array}{c}\text { Final } \\
\text { Extension }\end{array}$ & Cycles & $\begin{array}{c}\text { Expected } \\
\text { size }\end{array}$ & Reference \\
\hline \multirow[b]{2}{*}{ PCR } & $\begin{array}{l}\text { Avian } \\
\text { Adenovirus }\end{array}$ & $\begin{array}{c}\text { Hex } \\
\text { F1 } \\
\text { Hex } \\
\text { R1 }\end{array}$ & GAYRGYHGGRTNBTGGAYATGGG & $\begin{array}{l}94^{\circ} \mathrm{C}, 5 \\
\text { minutes }\end{array}$ & $\begin{array}{l}94^{\circ} \mathrm{C}, 1 \\
\text { minutes }\end{array}$ & $\begin{array}{c}55^{\circ} \mathrm{C} \\
1 \text { minute }\end{array}$ & $\begin{array}{c}72^{\circ} \mathrm{C} \\
30 \text { seconds }\end{array}$ & $\begin{array}{c}72^{\circ} \mathrm{C} \\
5 \text { minutes }\end{array}$ & 35 & 800 bp & $\begin{array}{l}\text { Mase et } \\
\text { al. (2009) }\end{array}$ \\
\hline & $\begin{array}{l}\text { Fowl } \\
\text { Adenovirus } \\
\text { Serotype-4 }\end{array}$ & $\begin{array}{l}\text { Fib } \\
\text { F1 } \\
\text { Fib } \\
\text { R1 }\end{array}$ & TTTGTCACGCGGTGGGGAGG & $\begin{array}{l}94^{\circ} \mathrm{C}, 5 \\
\text { minutes }\end{array}$ & $\begin{array}{l}94^{\circ} \mathrm{C}, 1 \\
\text { minutes }\end{array}$ & $\begin{array}{c}55^{\circ} \mathrm{C} \\
1 \text { minute }\end{array}$ & $\begin{array}{c}72^{\circ} \mathrm{C} \\
30 \text { seconds }\end{array}$ & $\begin{array}{c}72^{\circ} \mathrm{C} \\
5 \text { minutes }\end{array}$ & 35 & $1500 \mathrm{bp}$ & $\begin{array}{l}\text { Mase et } \\
\text { al. }(2010)\end{array}$ \\
\hline
\end{tabular}

Table 2. Biochemical properties of the FAdV4 strains from the oviducts of layer chicken farms located in Ibaraki Prefecture, Japan

\begin{tabular}{|c|c|c|}
\hline \multirow[b]{2}{*}{ Physical/chemical agents } & \multicolumn{2}{|c|}{ Strain titer } \\
\hline & $\begin{array}{c}\text { M-farm strain } \\
\text { (Japan/Ibaraki/M-HB2/2016) }\end{array}$ & $\begin{array}{c}\text { Y-farm strain } \\
(\text { Japan/Ibaraki/Y-H6/2016) }\end{array}$ \\
\hline Baseline Titer & $10^{5.40} \mathrm{TCID}_{50} / \mathrm{ml}$ & $10^{6.75} \mathrm{TCID}_{50} / \mathrm{ml}$ \\
\hline $100 \%$ ethanol & $10^{4.16} \mathrm{TCID}_{50} / \mathrm{ml} *$ & $10^{4.3} \mathrm{TCID}_{50} / \mathrm{ml} *$ \\
\hline $70 \%$ ethanol & $10^{5.30} \mathrm{TCID}_{50} / \mathrm{ml}$ & $10^{5.25} \mathrm{TCID}_{50} / \mathrm{ml}^{*}$ \\
\hline $50 \%$ ethanol & $10^{5.84} \mathrm{TCID}_{50} / \mathrm{ml}$ & $10^{7.5} \mathrm{TCID}_{50} / \mathrm{ml}$ \\
\hline $58^{\circ} \mathrm{C}$ & $10^{3.16} \mathrm{TCID}_{50} / \mathrm{ml}^{*}$ & $10^{4.69} \mathrm{TCID}_{50} / \mathrm{ml}^{*}$ \\
\hline $54^{\circ} \mathrm{C}$ & $10^{3.60} \mathrm{TCID}_{50} / \mathrm{ml}^{*}$ & $10^{3.59} \mathrm{TCID}_{50} / \mathrm{ml}^{*}$ \\
\hline $52^{\circ} \mathrm{C}$ & $10^{3.75} \mathrm{TCID}_{50} / \mathrm{ml}^{*}$ & $10^{4.5} \mathrm{TCID}_{50} / \mathrm{ml}^{*}$ \\
\hline $50^{\circ} \mathrm{C}$ & $10^{5.75} \mathrm{TCID}_{50} / \mathrm{ml}$ & $10^{6.50} \mathrm{TCID}_{50} / \mathrm{ml}$ \\
\hline formaldehyde & $10^{4.16} \mathrm{TCID}_{50} / \mathrm{ml}^{*}$ & $10^{5.25} \mathrm{TCID}_{50} / \mathrm{ml}^{*}$ \\
\hline ether & $10^{5.40} \mathrm{TCID}_{50} / \mathrm{ml}$ & $10^{6.40} \mathrm{TCID}_{50} / \mathrm{ml}$ \\
\hline chloroform & $10^{5.50} \mathrm{TCID}_{50} / \mathrm{ml}$ & $10^{6.36} \mathrm{TCID}_{50} / \mathrm{ml}$ \\
\hline
\end{tabular}

*At least $1 \log 10$ decrease in titer indicates sensitivity.

Table 3. Hemagglutinating Activity test results of the FAdV4 strains from the oviducts of layer chicken farms located in Ibaraki Prefecture, Japan

\begin{tabular}{l} 
Strain \\
\hline KR5 \\
M-farm strain (Japan/Ibaraki/M-HB2/2016) \\
Y-farm strain (Japan/Ibaraki/Y-H6/2016) \\
PBS* (negative control) \\
DadV-A (positive control) \\
$\begin{array}{l}\text { PBS: Phosphate buffered saline } \\
\text { Negative }\end{array}$ \\
To cite this paper: Del Valle FP, Camba ShI, Umali DV, Sasai K, Shirota K, and Katoh H (2021). Biochemical Properties and Cell Culture Affinity of Fowl Adenovirus Serotype-4 Strains Isolated from the Oviducts of Layer Hens in \\
East Japan. J. World Poult. Res., 11 (2): 241-251 DOI: https://dx.doi.org/10.36380/jwpr.2021.29
\end{tabular}


Table 4. Summary of cell culture cultivation results of FAdV4 strains from the oviducts of layer chicken farms located in Ibaraki Prefecture, Japan in CEF and MSB1 cells

\begin{tabular}{|c|c|c|c|c|c|c|c|c|c|c|}
\hline \multirow{2}{*}{ Passage } & & \multicolumn{3}{|c|}{ KR5 } & \multicolumn{3}{|c|}{ M-farm strain (Japan/Ibaraki/M-HB2/2016) } & \multicolumn{3}{|c|}{ Y-farm strain (Japan/Ibaraki/Y-H6/2016) } \\
\hline & & CPE & AAV-PCR & FAdV4-PCR & CPE & AAV-PCR & FAdV4-PCR & CPE & AAV-PCR & FAdV4-PCR \\
\hline \multirow{6}{*}{$\mathrm{CEF}$} & 1 & + & + & + & + & + & + & + & + & + \\
\hline & 2 & + & + & + & + & + & + & + & + & + \\
\hline & 3 & + & + & + & + & + & + & + & + & + \\
\hline & 4 & + & + & + & + & + & + & + & + & + \\
\hline & 5 & + & + & + & + & + & + & + & + & + \\
\hline & 6 & + & + & + & + & + & + & + & + & + \\
\hline \multirow{13}{*}{ MSB1 } & 1 & - & + & + & - & + & + & - & + & + \\
\hline & 2 & - & + & + & - & + & + & - & + & + \\
\hline & 3 & - & - & - & - & - & - & - & - & - \\
\hline & 4 & - & not tested & not tested & - & not tested & not tested & - & not tested & not tested \\
\hline & 5 & - & - & - & - & - & - & - & - & - \\
\hline & 6 & - & not tested & not tested & - & not tested & not tested & - & not tested & not tested \\
\hline & 7 & - & not tested & not tested & - & not tested & not tested & - & not tested & not tested \\
\hline & 8 & - & - & - & - & - & - & - & - & - \\
\hline & 9 & - & not tested & not tested & - & not tested & not tested & - & not tested & not tested \\
\hline & 10 & - & not tested & not tested & - & not tested & not tested & - & not tested & not tested \\
\hline & 11 & - & - & - & - & - & - & - & - & - \\
\hline & 12 & - & not tested & not tested & - & not tested & not tested & - & not tested & not tested \\
\hline & 13 & - & - & - & - & - & - & - & - & - \\
\hline
\end{tabular}

CPE: Cytopathic effect, AAV-PCR: Avian adenovirus polymerase chain reaction, FAdV4-PCR: Fowl adenovirus serotype-4 polymerase chain reaction

Table 5. Retrospective avian adenovirus-polymerase chain reaction testing of CAV-positive samples collected from layer chicken farms in Ibaraki Prefecture, Japan during 2017-2019

\begin{tabular}{|c|c|c|c|c|c|}
\hline \multirow{2}{*}{ Year } & \multirow{2}{*}{$\begin{array}{l}\text { Sampling } \\
\text { (months) }\end{array}$} & \multirow{2}{*}{$\begin{array}{c}\text { Laying Chickens } \\
\text { (total) }\end{array}$} & \multirow{2}{*}{$\begin{array}{l}\text { CAV-PCR* } \\
\text { positive }\end{array}$} & \multicolumn{2}{|c|}{ AAV-PCR** } \\
\hline & & & & Tested & Positive \\
\hline 2017 & January to December & 168 & 81 & 40 & 5 \\
\hline 2018 & January to December & 154 & 68 & 25 & 4 \\
\hline 2019 & January to August & 110 & 26 & 18 & 3 \\
\hline
\end{tabular}

CAV-PCR: Chick anemia virus-polymerase chain reaction. AAV-PCR: Avian adenovirus-polymerase chain reaction 

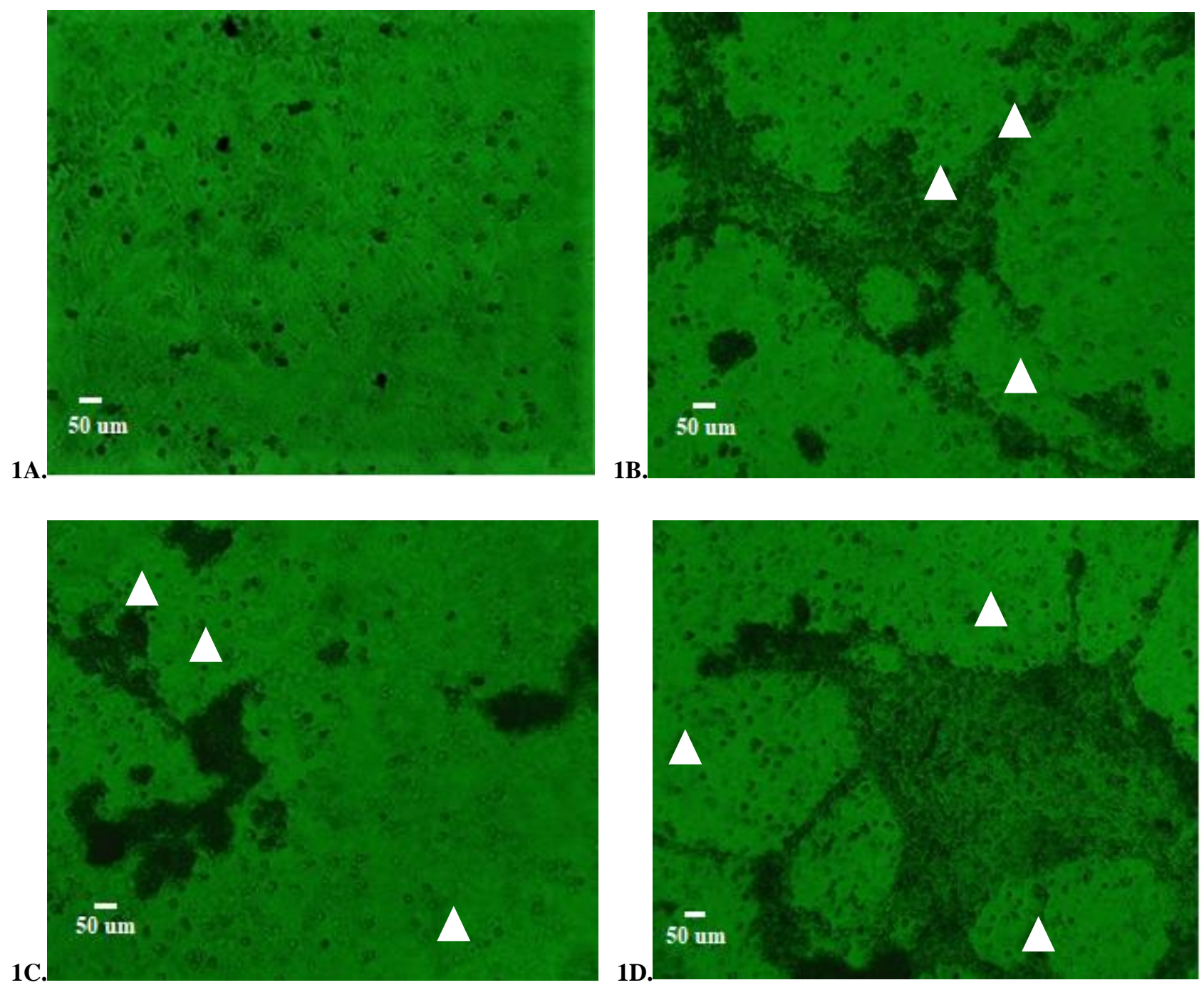

Figure 1. Representative chick embryo fibroblast observations, first passage, 2 dpi, LPO. 1A: Negative control, 1B: KR5 Positive control, cell swelling, rounding, and death (pointers), 1C: M farm sample-inoculated, cell swelling, rounding and death (pointers), 1D: Y farm sample-inoculated, cell swelling, rounding, and death (pointers)
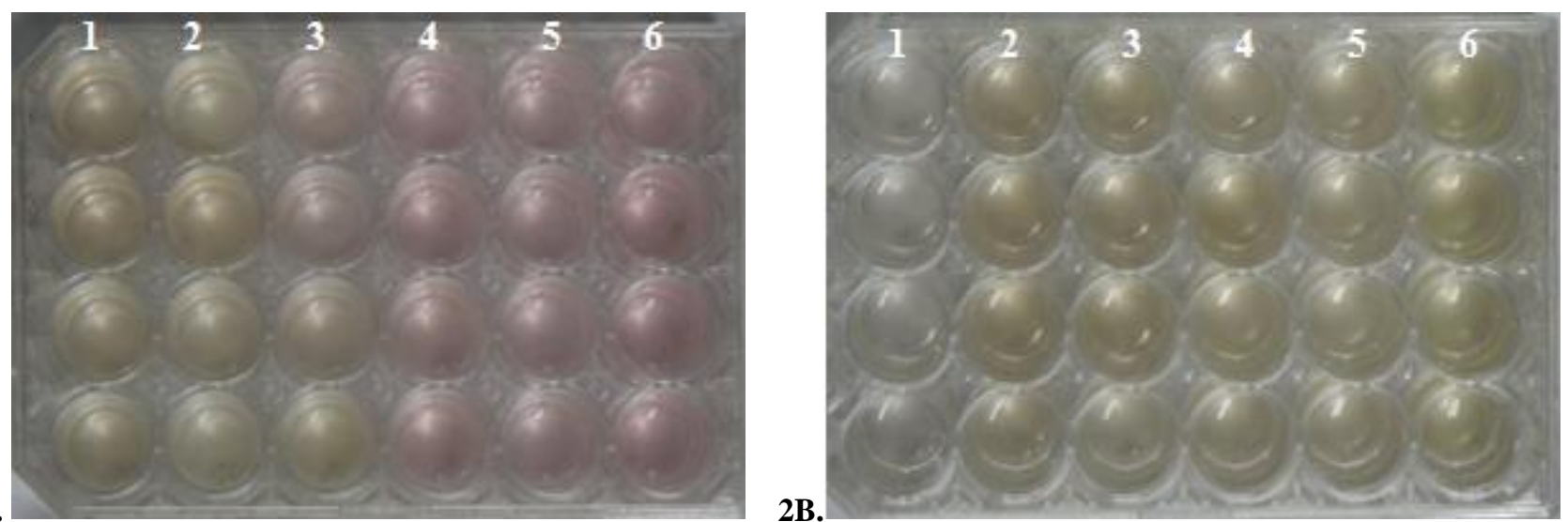

Figure 2. Representative MDCC-MSB1 gross observations, first to sixth passages. 2A: Live vaccine, color changes in replicates at the third passage indicate cell death, 2B: M-farm strain, no color change 
3A.
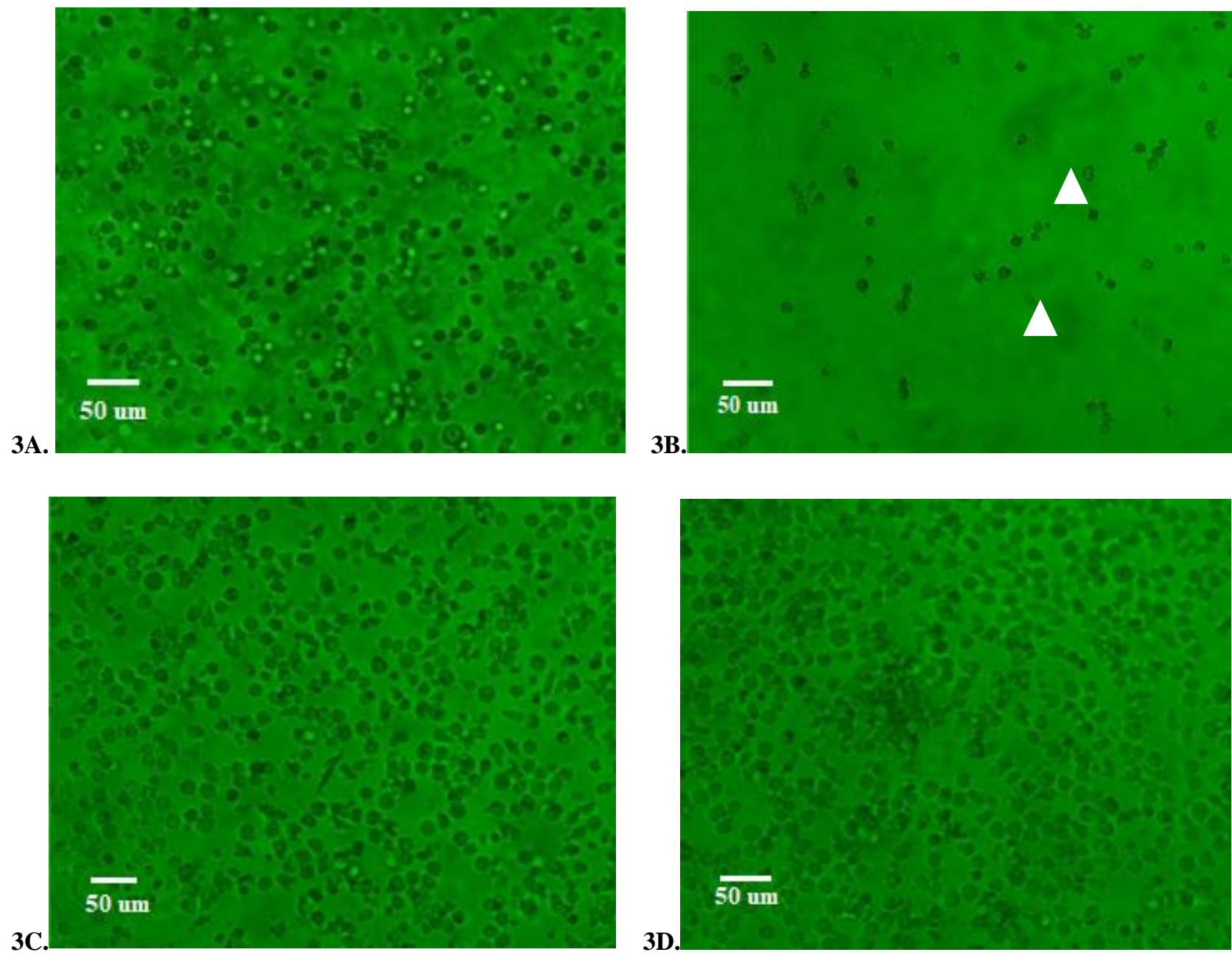

Figure 3. Representative MSB1cell cultivation microscopic observations at the 3rd passage. 3A: Negative control- rounded and numerous cells, 3B: Live-vaccine positive control, cellular swelling or wrinkling (pointers), apparently fewer cells, 3C: M farm strainrounded and numerous cells, 3D: Y farm strain- rounded and numerous cells

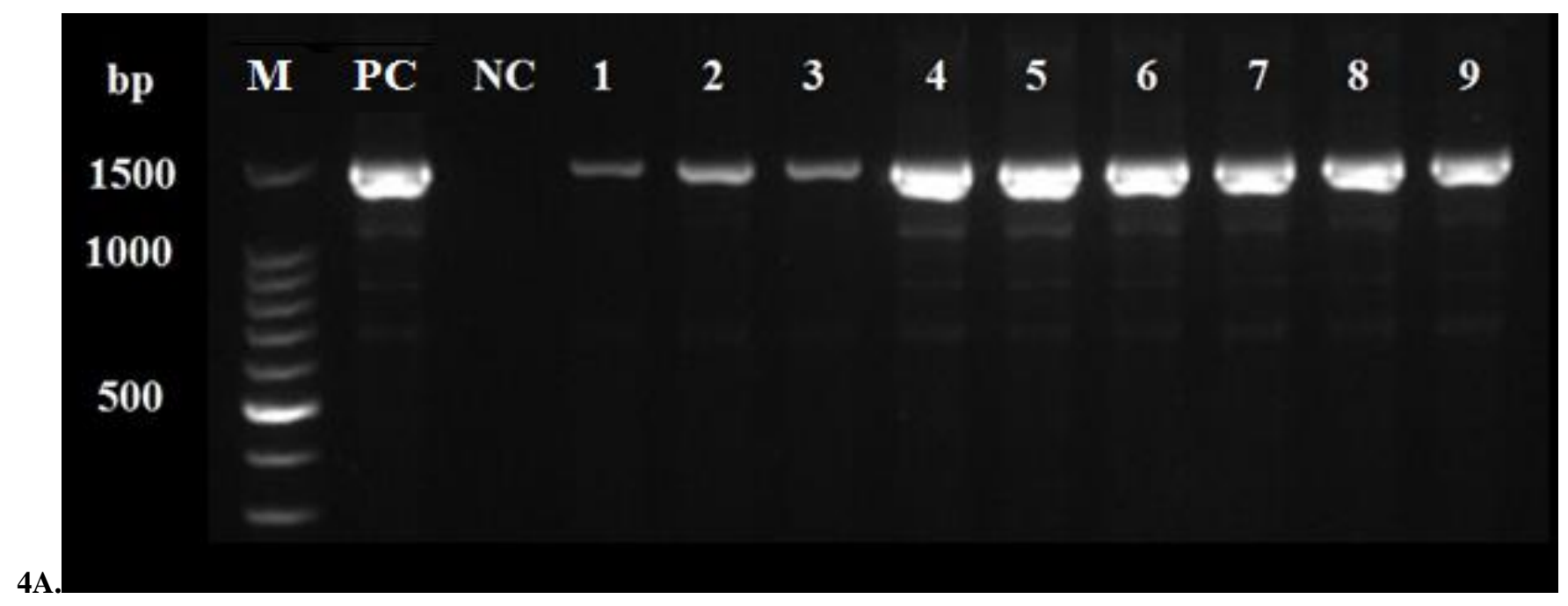


4B.

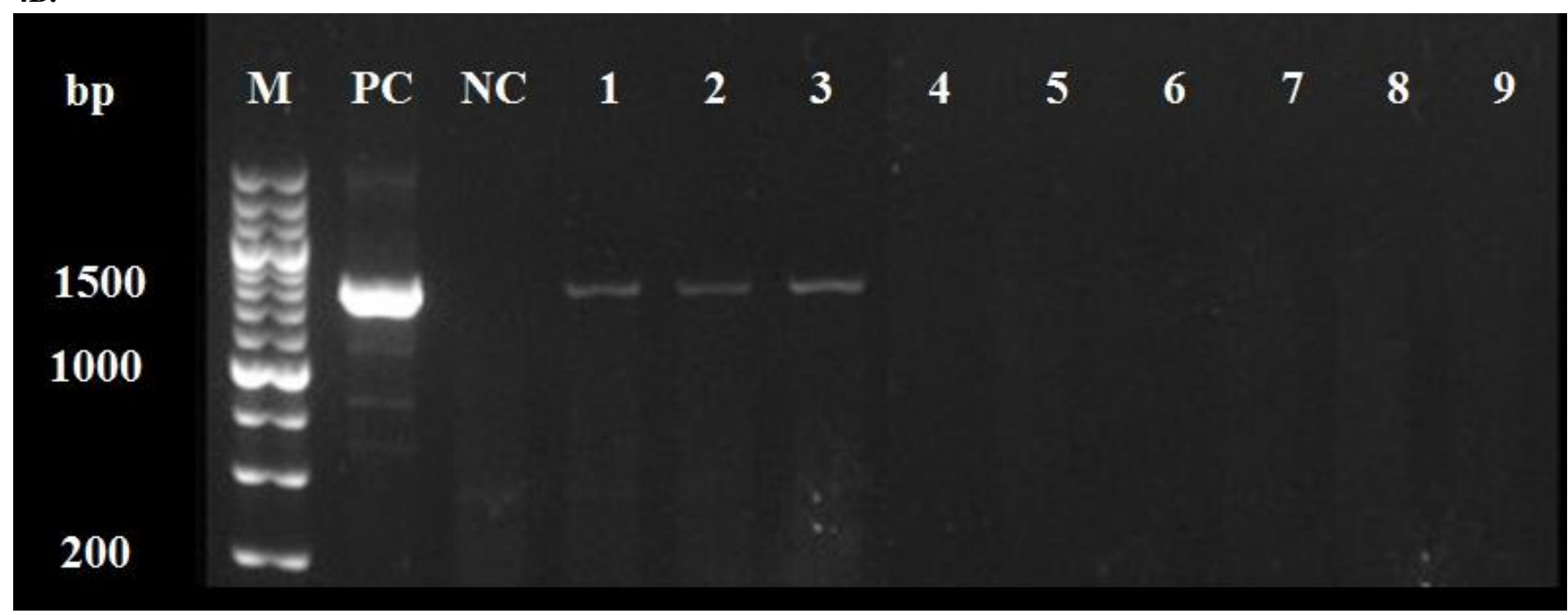

Figure 4. Representative FAdV-4 PCR results of CEF and MSB1 cultivation. 4A: CEF cultivation. Lane-M: 100bp ladder, Lane PC: positive control, Lane-NC: negative control, Lanes 1 to 3: KR5, M farm strain, and Y farm strain at 4th passage, Lanes 4 to 6: KR5, M farm strain, and $\mathrm{Y}$ farm strain at 5th passage, Lanes 7 to 9: KR5, M farm strain, and $\mathrm{Y}$ farm strain at 6th passage. 4B: MSB1 cultivation. Lane-M: 200bp ladder, Lane PC: positive control, Lane-NC: Negative control, Lanes 1 to 3: KR5, M farm strain, and Y farm strain at 2nd passage; Lanes 4 to 6: KR5, M farm strain, and Y farm strain at 8th passage, Lanes 7 to 9: KR5, M farm strain, and Y farm strain at 13th passage.

\section{DISCUSSION}

Before the advent of molecular methods, virus identification and characterization relied mostly on biochemical properties as described in earlier studies (Kawamura et al., 1964; Otsuki et al., 1976). However, even today, these basic techniques have remained useful for a couple of reasons. They do not require too many technical skills, thus, are less challenging to perform. Moreover, not all laboratories are equipped with the necessary resources and equipment for molecular-based diagnosis. Finally, the results of biochemical tests can supplement molecular data.

Both $\mathrm{M}$-farm and Y-farm strains are sensitive to $100 \%$ ethanol, $52^{\circ} \mathrm{C}$ or higher, diluted formaldehyde, and lack HA activity. These observations are consistent with the properties of FAdVs from Japan (Otsuki et al., 1976), Korea (Park et al., 2011), and the prototype strains (Kawamura et al., 1964). Although the strains in the current study were already confirmed as FAdV4 (Del Valle et al., 2020a), the presented data adds to the characterization of these strains and provides a wider picture. The virus sensitivity is now known which might be helpful in controlling virus environmental contamination. In both $\mathrm{M}$ and $\mathrm{Y}$ farms, AAV infection was confirmed. Perhaps, hot water sprays and formaldehyde disinfection can be included in the farm's cleanup and disinfection protocol. Ruano et al. (2001) mention disinfectants that can be effective against FAdVs. Although the role of the $\mathrm{M}$ and $\mathrm{Y}$ farm strains in poor egg production is not yet proven, it may be useful to start environmental control measures. Ideally, this should be applied in both layer and replacement pullet houses. In another study, it was found that pullets from the farm supplying $\mathrm{M}$ and $\mathrm{Y}$ farms were positive for CAV (Del Valle et al., 2020b). Some of these CAV-positive pullets were also AAV-positive (Table 5). This indicated that the replacement pullets received by $\mathrm{M}$ and $\mathrm{Y}$ farms could already be infected by FAdV4. It would also be ideal to check the parent stock for FAdV infection. All control measures would be useless if the progeny are infected from the start.

Initially, it was unknown if the $\mathrm{M}$ and $\mathrm{Y}$ farm strains had any HA activity; a characteristic present in DAdV-A which is known as a viral pathogen with affinity to the chicken oviduct. Now, it is clear that they do not share this characteristic. The latter agglutinates avian $\mathrm{RBC}$, which can aid in EDS diagnosis. The fiber protein is responsible for hemagglutination (Louis et al., 1994). Apparently, the FAdV4 isolates and DAdV-A fiber proteins have different properties. The negative HA results also confirmed the absence Orthomyxovirus and Paramyxovirus which can 
also produce round cell CPE in CEF or CKC (McFerran and Smyth, 2000).

The field strains and KR5 readily produced characteristic CPE on CEF, as well as good PCR results throughout cultivation. This may be attributed to the fact that the strains underwent multiple passages in CKC prior to titration and inoculation. One observation was that CPE in CEF appeared 5-6 days post-inoculation while CPE in CKC was visible as early as 2-3 days. This was consistent from the first passage throughout the study, meaning that strains replicate faster in CKC. Although it takes a longer time for CPE to appear, the use of CEF seems to be adequate for cultivating the strains. Chick embryo fibroblast is easier to prepare, compared to CKC or CEL. Moreover, the use of 10 to 14-day-old SPF chick embryos is more humane, compared to sacrificing day-old SPF chicks. Chick embryos are considered non-sentient until 17 days of incubation (Ribatti, 2016).

The field strains and KR5 did not produce CPE on MDCC-MSB1 cells. Viral DNA in MSB1 fluid was detectable only until the second passage after which results were all negative. MSB1 cells are derived from an MD lymphoma (Akiyama and Kato, 1974) and have the characteristics of helper T-lymphocytes (Adair et al., 1993). Since pathogenic FAdV4 can induce apoptosis in T-cells (Niu et al., 2019), it was hypothesized that the strains would affect MSB1 cells. CPE in MSB1 is characterized by cell death and failure to passage. Microscopically, the normally round cells become wrinkled or swollen, and the growth will stop (Simeonov et al., 2014). Gross color change in growth media also occurs. RPMI-1640, which is the usual media, will turn pink upon cell death. This CPE was observed only in the CAV-live vaccine-inoculated wells. Taharaguchi et al. (2012) observed adsorption of FAdV1 on the nonsusceptible cell lines Vero cell and Crandell-Rees Feline Kidney (CRFK) cell. However, the virus was only bound to the cellular surface without successful entry. Although no tests were performed to confirm it, perhaps the same occurred in the present study. FAdV4 may have adsorbed to the MSB1 cell surface only, but failed to induce endocytosis. The virus probably persisted in the media until it gradually disappeared.

The MSB1 cell line is used for the cultivation of CAV (Noteborn et al., 1994). Simeonov et al. (2014) cultivated CAV in MSB1 and observed CPE after three passages, and Yamaguchi et al. (2001) in 12. The FAdV4 strains in the current study cannot infect MSB1 even after 13 generations. The strains may not be virulent enough to cause CPE, or the cell line is not ideal for cultivation. To the best of the authors' knowledge, it is unknown if pathogenic FAdV4 strains can affect MSB1 cells which require future studies for further investigations. Cultivation of the virus in transformed cell lines may reduce the need for live animals. Some authors describe the use of QT35 (Schonewille et al., 2008) and LMH (Zhao et al., 2015) for cultivation. Unfortunately, these were unavailable at the time of experimentation.

\section{CONCLUSION}

The field strain's behavior and properties are similar to other fowl adenovirus strains. These are sensitive to pure and diluted ethanol, $52^{\circ} \mathrm{C}$ or higher, and diluted formaldehyde, they also lack hemagglutinating activity. Potentially, it is time to initiate environmental control measures in the farms, which could be supplemented with the knowledge of the viruses' sensitivity. The field strains, which are non-pathogenic fowl adenovirus serotype-4, cannot infect MSB1 cells in spite of multiple passages. However, there appear to be no reports on the effect of pathogenic fowl adenovirus serotype- 4 on that cell line. Considering the fact that the effect on T-cells has been reported by other researchers, perhaps the interaction between pathogenic fowl adenovirus serotype-4 and MSB1 cells could be studied in the future.

\section{DECLARATIONS}

\section{Acknowledgments}

This work was supported by the funding of Katoh Masako of the PPQC Scholarship Foundation (Nihonmatsu, Fukushima, Japan). Ishii Makiko, Kashima Eri, and Tsugeno Rena from PPQC, Ltd. (Nihonmatsu, Fukushima, Japan) also contributed thru their laboratory skills. Finally, the authors would like to thank Dr Gouda Mitsuaki of the Gouda Poultry Clinic (Okazaki, Aichi, Japan) for providing the KR5 strain used in this study.

\section{Competing interests}

The authors declare that they have no competing interests.

\section{Consent to publish}

All authors contributed equally to the accomplishment of this work, and gave their informed consent prior to inclusion.

\section{Authors' contribution}

All authors participated in the conceptualization, experimentation, interpretation of results, and preparation of this paper. 


\section{Ethical considerations}

The authors confirm that all of the ethical issues and rules concerning: plagiarism, consent to publish, misconduct, data fabrication, and/or falsification, double publication and/or submission, and redundancy, have all been checked and adhered to.

\section{REFERENCES}

Absalón A, Morales-Garzón A, Ver-Hernandez PF, CortesEspinoza DV, Uribe-Ochoa SM, Garcia LJ, and LucioDecanini E (2017). Complete genome sequence of a nonpathogenic strain of Fowl adenovirus serotype 11: minimal genomic differences between pathogenic and nonpathogenic viruses. Virology, 501: 63-69. DOI: https://www.doi.org/10.1016/j.virol.2016.11.006

Adair BM, McNeilly F, McConnell CDG, and McNulty MS (1993). Characterization of surface markers present on cells infected by Chicken anemia virus in experimentally infected chickens. Avian Diseases, 37: 943-950. DOI: https://www.doi.org/10.2307/1591898

Akiyama Y, and Kato S (1974). Two cell lines from lymphomas of Marek's disease. Biken Journal, 17: 105-116. Available at https://pubmed.ncbi.nlm.nih.gov/4616680/

Bauer HJ, Hauschild S, Logemann K, Hehlein K, and Monreal G (1986). Avian adeno-associated virus (AAAV) and fowl adenoviruses (FAV): Studies on viral interactions in chicken cell cultures. Avian Pathology, 15: 357-366. DOI: https://www.doi.org/10.1080/03079458608436299

Cook JKA (1983). Fowl adenoviruses: studies on aspects of the pathogenicity of six strains for 1-day-old chicks. Avian Pathology, 12(1): 35-43. DOI: https://www.doi.org/10.1080/03079458308436147

Del Valle FP (2019). Molecular and pathological characterization of avian adenovirus isolated from the oviducts of laying hens in eastern Japan. PhD Thesis. Osaka Prefecture University. Available at: https://acaddb.com/dissertations/articles/663181).

Del Valle FP, Camba SI, Umali DV, Sasai K, Shirota K, Katoh H, and Tajima T (2020a). Molecular and pathological characterization of avian adenovirus isolated from the oviducts of laying hens in eastern Japan. Poultry Science, 99: 2459-2468. DOI: https://www.doi.org/10.1016/j.psj.2019.12.059

Del Valle FP, Camba SI, Umali DV, Sasai K, Shirota K, Katoh H and Tajima $T$ (2020b). The diseases suspected of the involvement of chicken anemia virus infection in 11 to 14weeks old replacement pullets from eastern Japan: a case report. Journal of Veterinary Medical Science, 82(5): 520526. DOI: https://www.doi.org/10.1292/jvms.19-0210

Fujino K, Fujimoto Y, Ujino A, Thanasut K, Taharaguchi M, Taharaguchi S, and Takase K (2016). Gallus gallus coxsackievirus and adenovirus receptor facilitates the binding of fowl adenovirus serotype 1 in chickens. Japanese Journal of Veterinary Research, 64(3): 183-190. DOI: https://www.doi.org/10.14943/jjvr.64.3.183

Grafl B, Aigner F, Liebhart D, Marek A, Prokofieva I, Bachmeier J, and Hess M (2012). Vertical transmission and clinical signs in broiler breeders and broiler. Avian
Pathology, 41(6): 599-604. DOI: https://www.doi.org/10.1080/03079457.2012.740614

Harrach B, Benko M, Both GW, Brown M, Davison AJ, Echavarria M, Hess M, Jones MS, Kajon A, Lehmkuhl $\mathrm{HD}$, et al. (2011). Family Adenoviridae. In Virus taxonomy: classification and nomenclature of viruses. Ninth report of the International Committee on Taxonomy of Viruses. (King, A.M.Q., Adams, M.J., Carstens, E.B., Lefkowitz, E.J. eds). Elsevier, San Diego.

Hess M (2000). Detection and differentiation of avian adenoviruses: $\underline{A}$ review. Avian Pathology, 29: 195-206. DOI: https://www.doi.org/10.1080/03079450050045440

Hess M. (2017). Commensal or pathogen - a challenge to fulfil Koch's Postulates. British Poultry Science, 58(1): 1-12, DOI: https://www.doi.org/10.1080/00071668.2016.1245849

(ICTV) International Committee on Taxonomy of Viruse (2018). Spreadsheet of current taxonomy, master species list. Available https://talk.ictvonline.org/taxonomy/p/taxonomy releases

Joubert HW, Aitchison H, Maartens LH, and Venter EH (2014). Molecular differentiation and pathogenicity of aviadenoviruses isolated during an outbreak of inclusion body hepatitis in South Africa. Journal of the South African Veterinary Association, 85(1): Article number 1058, DOI: https://www.doi.org/10.4102/jsava.v85i1.1058

Kawamura H, Shimizu F, and Tsubahara H (1964). Avian adenovirus: its properties and serological classification. National Institute Animal Health Quarterly, 4(4): 183-193.

Knowles DP (2011). Adenoviridae. In: Mac Lachlan, N.J., and Dubovi, E.J (Editors), Fenner's Veterinary Virology, 4th Edition. Academic Press Elsevier Inc., London, pp. 203212.

Liu Y, Wan W, Gao D, Li Y, Yang X, Liu H, Yao H, Chen C, Wang C, and Zhao J (2016). Genetic characterization of novel fowl adenovirus 4 isolates from outbreaks of hepatitis-hydropericardium syndrome in broiler chickens in China. Emerging Microbes and Infection, 5: e117. DOI: https://www.doi.org/10.1038/emi.2016.115

Louis N, Fender P, Barge A, Kitts P, and Chroboczek J (1994). Cell-binding domain of adenovirus serotype 2 fiber. Journal of Virology, 68(6): 4104-4106. DOI: https://www.doi.org/10.1128/jvi.68.6.4104-4106.1994

Mase M, Nakamura K, and Imada T (2010). Characterization of Fowl adenovirus serotype 4 isolated from chickens with hydropericardium syndrome based on the analysis of the short fiber protein gene. Journal of Veterinary Diagnostic Investigation, 22: 218-223. 201 https://www.doi.org/10.1177/104063871002200207

Mase M, Mitake H, Inoue T, and Imada T (2009). Identification of group I-III adenovirus by PCR coupled with direct sequencing of the hexon gene. Journal of Veterinary Medical Science, 71: 1239-1242. DOI: https://www.doi.org/10.1292/jvms.71.1239

Matczuk A, Niczyporuk JS, Kuczkowski M, Wozniakowski G, Nowak M, and Wieliczko A (2017). Whole genome sequencing of fowl aviadenovirus A- a causative agent of gizzard erosion and ulceration, in adult laying hens. Infection Genetics and Evolution, 48: 47-53. DOI: https://www.doi.org/10.1016/j.meegid.2016.12.008 
McFerran JB, and Smyth JA (2000). Avian Adenoviruses. Revue Scientifique et Technique (International Office of Epizootics), 19(2): 589-601. DOI: https://www.doi.org/10.20506/rst.19.2.1238

Mo K, Lyu C, Cao S, Li X, Xing G, Yan Y, Zheng X, Liao M, and Zhou J (2019). Pathogenicity of an FAdV-4 isolate to chickens and its genomic analysis. Biomedicine and Biotechnology, 20(9): 740-752. DOI: https://www.doi.org/10.1631/jzus.B1900070

Nakamura K, Mase M, Yamamoto Y, Takizawa K, Kabeya M, Wakuda T, Matsuda M, Chikuba T, Yamamoto Y, Ohyama T, et al. (2011). Inclusion body hepatitis caused by fowl adenovirus in broiler chickens in Japan, 20092010. Avian Diseases, 55: 719-723. DOI: https://www.jstor.org/stable/41418392

Nakamura K, Mase M, Yamaguchi S, and Yuasa N (2000). Induction of hydropericardium in one-day-old specificpathogen-free chicks by adenovirus from inclusion body hepatitis. Avian Diseases, 44: 192-196. DOI: https://www.doi.org/10.2307/1592524

Niczyporuk JS, Wozniakowski G, Salamonowicz ES, and Czekaj $\mathrm{H}$ (2013). Effect of fowl adenovirus on replication of vaccine strain of Marek's disease virus in chickens. Bulletin of the Veterinary Institute in Pulawy, 57: 467-472. DOI: https://www.doi.org/10.2478/bvip-2013-0081

Niczyporuk JS, Samorek-Salamonowicz E and Czekaj H (2012). Occurrence of adenovirus field strains in birds infected with Marek's disease virus. Bulletin of the Veterinary Institute in Pulawy, 56: 435-440. DOI: https://www.doi.org/10.2478/v10213-012-0077-2

Niu Y, Sun Q, Shi Y, Ding Y, Li Z, Sun Y, Li M, and Liu S (2019). Immunosuppressive potential of fowl adenovius serotype 4. 2019. Poultry Science, pp 1-9. DOI: https://www.doi.org/10.3382/ps/pez179

Noteborn MHM, Todd D, Verschueren CAJ, De Gauw HWFM, Curran WL, Veldkamp S, Douglas AJ, Mcnulty MS, Van der Eb AJ, and Koch G (1994). A single chicken anemia virus protein induces apoptosis. Journal of Virology, 68(1): 346-351. DOI: https://www.doi.org/10.1128/jvi.68.1.346$\underline{351.1994}$

Okuda Y, Ono M, Shibata I, Sato S, and Akashi H (2006). Comparison of the polymerase chain reaction-restriction fragment length polymorphism pattern of the fiber gene and pathogenicity of serotype- 1 fowl adenovirus isolates from gizzard erosions and from feces of clinically healthy chickens in Japan. Journal of Veterinary Diagnostic Investigation, $\quad 18$ : 162-167. DOI: https://www.doi.org/10.1177/104063870601800204

Ono M, Okuda Y, Yazawa S, Shibata I, Tanimura N, Kimura K, Haritani M, Mase M, and Sato S (2001). Epizootic outbreaks of gizzard erosion associated with adenovirus in chickens. Avian Diseases, 45: 268-275. DOI: https://www.doi.org/10.2307/1593040

Otsuki K, Tsuokura M, Yamamoto H, and Imamura M (1976). Some properties of avian adenoviruses isolated from chickens. Avian Diseases, 20(4): 693-705. DOI: https://www.doi.org/10.2307/1589449

Park H, Lim I, Kim S, Kim T, and Yeo S (2011). Isolation and characterization of fowl adenovirus serotype 4 from chickens with hydropericardium syndrome in Korea. Korean Journal of Veterinary Research, 51(3): 209-216. DOI: https://www.doi.org/10.14405/kjvr.2011.51.3.209

Reed LJ, and Muench H (1938). A simple method of estimating fifty percent endpoints. American Journal of Epidemiology, 27(3):493497. DOI: https://www.doi.org/10.1093/oxfordjournals.aje.a118408

Ribatti D (2016). The chick embryo chorioallantoic membrane (CAM). A multifaceted experimental model. Mechanisms of Development, 141:70-77. DOI: https://www.doi.org/10.1016/j.mod.2016.05.003

Rovozzo G, and Burke C (1973). A manual of basic virological techniques. Prentice Hall Inc., New Jersey, pp. 82-93, 126151.

Ruano M, El-Attrache M, and Villegas P (2001). Efficacy comparisons of disinfectants used by the commercial poultry industry. Avian Diseases, 45: 972-977. DOI: https://www.doi.org/10.2307/1592876

Schonewille E, Singh A, Gobel TW, Gerner W, Saalmuller A, and Hess M (2008). Fowl adenovirus (FAdV4) serotype 4 causes depletion of $\mathrm{B}$ and $\mathrm{T}$ cells in lymphoid organs in specific pathogen-free chickens following experimental infection. Veterinary Immunology and Immunopathology, 121: 130-139. DOI: https://www.doi.org/10.1016/j.vetimm.2007.09.017

Simeonov KB, Petrova RT, Gyurov BI, Peshev RD, and Mitov BK (2014). Isolation and PCR identification of chicken anemic virus infection in Bulgaria. Bulgarian Journal of Veterinary Medicine, 17(4): 276-284. Available at: http://tru.uni-sz.bg/bjvm/bjvm.htm

Taharaguchi S, Fukazawa R, Kitazume M, Harima H, Taira K, Oonaka K, and Hara M (2012). Biology of fowl adenovirus type 1 infection of heterologous cells. Archives of Virology, 157: 2223-2226. DOI: https://www.doi.org/10.1007/s00705-012-1413-9

H. Toro, O. Gonzales, C. Escobar, L. Cerda, M.A. Morales, C. Gonzales (2001). Vertical induction of the inclusion body hepatitis/hydropericardium syndrome with fowl adenovirus and chicken anemia virus, Avian Diseases. 45 (2001), pp. 215-222 DOI: https://www.doi.org/10.2307/1593031

Yamaguchi S, Imada $\mathrm{T}$, Kaji $\mathrm{N}$, Mase $\mathrm{M}$, Tsukamoto $\mathrm{K}$, Tanimura N, and Yuasa N (2001). Identification of genetic determinant of pathogenicity in chicken anemia virus. Journal of General Virology, 82: 1233-1238. DOI: https://www.doi.org/10.1099/0022-1317-82-5-1233

Zhao J, Zhong Q, Zhao Y, Hu Y, and Zhang G (2015). Pathogenicity and complete genome characterization of fowl adenoviruses isolated from chickens associated with inclusion body hepatitis and hydropericardium syndrome in China. PLoS ONE, 10(7):e0133073. DOI: https://www.doi.org/10.1371/journl.pone 